\title{
Short communication: Effects of increasing protein and energy in the milk replacer with or without direct-fed microbial supplementation on growth and performance of preweaned Holstein calves
}

\author{
A. J. Geiger, ${ }^{*}$ S. H. Ward, ${ }^{* 1}$ C. C. Williams, $†$ B. J. Rude, ${ }^{*}$ C. J. Cabrera, ${ }^{*}$ K. N. Kalestch, ${ }^{*}$ and B. E. Voelz \\ ${ }^{*}$ Department of Animal and Dairy Sciences, Mississippi State University, Mississippi State 39762 \\ †School of Animal Sciences, Louisiana State University, Baton Rouge 70803
}

\begin{abstract}
Forty-four Holstein calves were fed a direct-fed microbial (DFM) and 1 of 2 milk replacers to evaluate calf performance and growth. Treatments were (1) a control milk replacer $[22: 20 ; 22 \%$ crude protein (CP) and $20 \%$ fat], (2) an accelerated milk replacer $(27: 10 ; 27 \% \mathrm{CP}$ and $10 \%$ fat), (3) the control milk replacer with added DFM $(22: 20+D)$, and (4) the accelerated milk replacer with added DFM (27:10+D). Dry matter intake, rectal temperatures, respiration scores and rates, and fecal scores were collected daily. Body weight, hip and withers height, heart girth, blood, and rumen fluid samples were collected weekly. Effects of treatment, sex, week, and their interactions were analyzed. Calves fed an accelerated milk replacer, regardless of DFM supplementation, consumed more $\mathrm{CP}$ and metabolizable energy in the milk replacer. No treatment differences were found for starter intake or intake of neutral detergent fiber or acid detergent fiber in the starter. Calves fed the accelerated milk replacer had greater preweaning and weaning body weight compared with calves fed the control milk replacer. Average daily gain was greater during the preweaning period for calves fed the accelerated milk replacer, but the same pattern did not hold true during the postweaning period. Feed efficiency did not differ among treatments. Hip height tended to be and withers height and heart girth were greater at weaning for calves fed the accelerated milk replacer compared with calves fed the control milk replacer. Fecal scores were greatest in calves fed DFM. Overall acetate, propionate, butyrate, and $n$-valerate concentrations were lower in calves fed the accelerated milk replacer, but DFM did not have an effect. Rumen $\mathrm{pH}$ was not different. Blood metabolites were unaffected by DFM supplementation, but calves fed the accelerated milk replacer had increased partial pressure of $\mathrm{CO}_{2}$, bicarbonate, and total bicarbonate in the blood. Direct-fed
\end{abstract}

Received May 6, 2013

Accepted June 13, 2014.

${ }^{1}$ Corresponding author: srhill@ads.msstate.edu microbial supplementation did not appear to benefit the calf in this trial

Key words: dairy calf, direct-fed microbial, milk replacer

\section{Short Communication}

Feeding an increased amount of $\mathrm{CP}$ in the milk replacer $(\mathbf{M R})$ increased ADG $(P<0.01)$ in preweaned dairy calves by up to $0.65 \mathrm{~kg} / \mathrm{d}$ (Lassiter et al., 1963 ; Nonnecke et al., 2003; Cowles et al., 2006). Multiple reports of improved feed:gain ratios $(P<0.01$; Cowles et al., 2006), frame measurements $(P<0.05$; Cowles et al., 2006; Raeth-Knight et al., 2009), and DMI of up to $211 \mathrm{~g} / \mathrm{d}(P<0.01$; Cowles et al., 2006) were noted as a result of increased CP in MR. Nonnecke et al. (2003) saw as much as a $53 \%$ increase in mean BW at d 60 of age when calves were fed increased CP concentrations (30\%) compared with the control $(20 \%)$.

Previous research has also indicated beneficial growth results when ME intake is increased. Bartlett et al. (2006) found that BW, ADG, and feed efficiency improved when calves consumed ME at a rate of 4.41 versus $2.96 \mathrm{Mcal} / \mathrm{d}$, regardless of protein intake. In that trial, Holstein bull calves were fed MR at varying CP concentrations $(14,18,22$, or $26 \%)$ and feeding rates (1.25 or $1.75 \%$ of BW) after the conclusion of a 2 -wk adaptation period. After a 5 -wk feeding period, calves consuming greater amounts of ME had increased BW by roughly $10 \mathrm{~kg}(P<0.01)$ and those same calves had increased ADG during that same 5-wk feeding period $(0.62$ vs. $0.33 \mathrm{~kg} / \mathrm{d}$, respectively; $P<0.01)$. For both $\mathrm{BW}$ and $\mathrm{ADG}$, linear increases were also found as CP consumption was increased. Feed efficiency was also improved for animals consuming greater ME $(P<0.01)$. Another trial found linear increases in ADG and feed efficiency when CP content of the MR was increased and ME intake remained similar (Blome et al., 2003).

By feeding an MR with increased $\mathrm{CP}$ and $\mathrm{ME}$ content, combined with a direct-fed microbial (DFM), availability and utilization of nutrients could be increased. This increase in available nutrients accompanied by an 
increase in DMI could lead to improved rumen development, improved ADG in the preweaning phase, and increased BW at weaning in dairy calves. Therefore, the objectives of this study were to evaluate the effects of increased CP in the MR with or without a DFM supplement on performance and growth of dairy calves.

During the months of August through December 2012, 44 Holstein calves (9 males and 35 females; birth weight $=34.19 \pm 4.9 \mathrm{~kg}$ ) from Mississippi State University (Mississippi State) were randomly assigned at birth to 1 of 4 treatments in a $2 \times 2$ factorial arrangement of treatments: a control MR [22:20 (22\% protein:20\% fat); Land O'Lakes Inc., St. Paul, MN], an accelerated MR with increased $\mathrm{CP}$ and decreased fat concentrations [27:10 (27\% protein:10\% fat); Land O'Lakes Inc.], 22:20 with the addition of a DFM (22:20+D; Calf RD; TechMix Inc., Stewart, MN), or 27:10 with the addition of the DFM $(\mathbf{2 7 : 1 0 + D )}$. Upon birth, calves were esophageally tube fed $1.8 \mathrm{~L}$ of colostrum, as is protocol at the Mississippi State University Bearden Research Dairy. Calves were fed milk twice daily at 0600 and 1800 $\mathrm{h}$, housed in hutches $(212 \times 117 \times 122 \mathrm{~cm}$ usable calf space), and bedded with straw. After 35 d calves were fed once daily and weaned at $42 \mathrm{~d}$. Calves remained in hutches until 56 d. Calves were fed using buckets. Milk replacer was fed at $15 \%$ solids content, mixed, and fed based on the manufacturer's recommendations. Calves fed 22:20 were given $567 \mathrm{~g}$ of $\mathrm{MR} / \mathrm{d}$, which was reduced to $283 \mathrm{~g} / \mathrm{d}$ during wh 5 , whereas calves fed 27:10 were fed $816 \mathrm{~g}$ of powder/d during the first 2 wk and 1,134 $\mathrm{g} / \mathrm{d}$ during wk 3 and 4 , which was reduced to $567 \mathrm{~g} / \mathrm{d}$ during wk 5 . Direct-fed microbial supplementation was given at $2 \mathrm{~g}$ per feeding ( $4 \mathrm{~g} / \mathrm{head}$ per day) and mixed into the MR, as suggested by the manufacturer. Calves were offered starter $(18 \% \mathrm{CP}$ and $2 \%$ fat; Purina Mills LLC, St. Louis, MO) from d 1 of the trial and offered water free choice. Starter was given at a rate of $2.3 \mathrm{~kg} /$ head per day until orts decreased to less than $0.45 \mathrm{~kg} /$ head per day and was then increased to $4.6 \mathrm{~kg} / \mathrm{head}$ per day.

Body weight, withers height, hip height, and heart girth were measured weekly on Thursdays at $1400 \mathrm{~h}$. The same 3 graduate assistants took rectal temperatures, respiration rates and scores, and fecal scores daily. Respiratory scores were defined as $1=$ normal, 2 $=$ runny nose, $3=$ heavy breathing, $4=$ moist cough, and $5=$ dry cough. Fecal scores were defined as $1=$ normal and solid; $2=$ slightly loose; $3=$ slightly discolored, obvious scours; and $4=$ discolored, extreme scours (Larson et al., 1977). Feed samples were taken weekly and compiled by month. Orts (feed refusals) were weighed daily and sampled weekly. Feed and orts samples were subjected to proximate analysis, including $\mathrm{DM}, \mathrm{NDF}$, and $\mathrm{ADF}$, according to Goering and
Van Soest (1970). Crude protein content was determined using the Kjeldahl $\mathrm{N}$ method (AOAC, 1990). Fat content was determined by ether extraction: $2 \mathrm{~g}$ of sample were placed in alundum crucibles and placed in a Goldfisch ether extraction apparatus (model 35001; ExpotechUSA Inc., Houston, TX) with $40 \mathrm{~mL}$ of ether. Samples were boiled in ether for $4 \mathrm{~h}$, dried at $100^{\circ} \mathrm{C}$ for at least $24 \mathrm{~h}$, and weighed. Metabolizable energy was calculated using the calf diet ME equation from NRC (2001) as follows:

$$
\text { Milk ME }=\text { milk ME }+(\text { DM fed } \times \text { cMEng }),
$$

where cMEng was the concentration of ME in the milk, calculated as

$$
\begin{gathered}
\mathrm{ME}(\mathrm{Mcal} / \mathrm{kg} \text { of } \mathrm{DM})=[0.057 \times \mathrm{CP}(\%)+0.092 \\
\times \text { fat }(\%)+0.0395 \times \text { lactose }(\%)] \times 0.9312
\end{gathered}
$$

Rumen fluid samples were collected at wk 4, 6, and 8 during weekly growth measurements via esophageal tubing. A tube was inserted into the mouth of the calf and fed down the esophagus. A 60-mL syringe was used to draw rumen fluid from the rumen. Rumen $\mathrm{pH}$ was recorded with a $\mathrm{pH}$ meter $(\mathrm{pH} 6+$ portable meter kit; Oakton Instruments, Vernon Hills, IL) and rumen fluid was mixed with $1 \mathrm{~mL}$ of phosphoric acid and stored at $-20^{\circ} \mathrm{C}$. Upon thawing, rumen fluid was strained through cheesecloth and centrifuged at $3,000 \times \mathrm{g}$ for 30 min at $22^{\circ} \mathrm{C}$. Rumen fluid was strained again to remove all impurities. Four milliliters of rumen fluid was mixed with $1 \mathrm{~mL}$ of metaphosphoric acid solution containing 2-ethyl butyric acid [25\% (wt/vol) metaphosphoric acid containing $2 \mathrm{~g}$ of 2-ethyl butyric acid/L] and analyzed for VFA by gas-liquid chromatography using a Shimadzu GC 2010 (Shimadzu Corp., Kyoto, Japan) equipped with a 15-m EC 1000 column (Alltech Associates Inc., Deerfield, IL). The procedures for reagent preparation and the temperature gradient for the VFA analysis were the same as conducted by Grigsby et al. (1992) and Bateman et al. (2002).

Blood was collected from all calves at $18 \mathrm{~h}$ after birth and weekly thereafter before weekly growth measurements $(1400 \mathrm{~h})$. Blood was collected via jugular venipuncture using $10-\mathrm{mL}$ evacuated tubes. Only initial blood samples at birth were used to determine IgG concentrations (Bova-S; VMRD Inc., Pullman, WA) before the onset of the trial. Heparin-coated tubes were brought to the laboratory at the dairy for analysis of blood gas and electrolytes using the Idexx Vet Stat blood gas and electrolyte analyzer (Idexx Laboratories Inc., Westbrook, ME). Blood was drawn into microcentrifuge tubes from the heparinized tube and centrifuged 
in a microcentrifuge (model MH/120; Ample Scientific LLC, Norcross, GA) at $14,000 \times g$ for $90 \mathrm{~s}$ at $22^{\circ} \mathrm{C}$ and hematocrit content was determined after. Tubes were then broken and serum was placed on a Reichert Goldberg Clinical Hand-held refractometer (Reichert Technologies, Depew, NY) and serum protein content was determined. Blood glucose content was determined using a Bayer hand-held glucometer (Bayer AG, Leverkusen, Germany) by drawing blood directly from heparinized blood tubes.

This study was a $2 \times 2$ factorial arrangement of treatments in a completely randomized design, where treatment $(22: 20,22: 20+\mathrm{D}, 27: 10$, and $27: 10+\mathrm{D})$, sex, and week (or day) were included in the model with all possible interactions examined. Main effects of MR, DFM, and their combined interaction were analyzed as main effects in the factorial design. Data were analyzed by ANOVA, using PROC MIXED of SAS (SAS Institute, 2004). Data with multiple measures per calf were analyzed by repeated measures (day or week) and calf was defined as a random effect. The slice statement was used to determine significant effects within week. Birth weight was defined as a covariate for BW analyses. Initially, birth month was included in the model, but was not significant and was removed. Interactions that were not significant were removed from the model. Significance was declared at $P<0.05$ and trends were declared when $0.05<P<0.10$. Presented data includes a $P$-value for the main effects of MR type, DFM supplementation (DFM), and the combined interaction of MR type and DFM supplementation $(\mathrm{MR} \times \mathrm{DFM})$.

\section{Diet Composition and Intake Data}

Nutrient concentrations in the MR and starter feed were similar to that reported by the manufacturer (Table 1). Metabolizable energy content of the MR (as calculated) was numerically lower in 27:10. As designed, calves fed 22:20 had decreased MR DMI compared with calves fed $27: 10$ (0.54 vs. $0.85 \mathrm{~kg} / \mathrm{d}$, respectively; $P<$ 0.01; Table 2). As a result, $\mathrm{CP}$ and ash intake from MR were greater in calves fed 27:10. Even though concentrations of ME were lower in 27:10, increased intake of powder resulted in increased ME intake from the MR. Because fat content of 27:10 was about half of 22:20, fat intake from MR was not different $(P=0.23)$. Addition of DFM did not affect nutrient intake from MR or starter. No differences existed in starter DM or other nutrient intake. However, because of differences in MR intakes, total DMI was different. Calves fed 27:10 had greater total DM, CP, and ash intake than calves fed 22:20. Supplementation of DFM did not affect total nutrient intake, but an interaction of MR and DFM was detected, where calves fed 22:20+D had greater nutrient intakes (DM, CP, fat, NDF, ADF, and ash) compared with 22:20, but lesser nutrient intakes than calves fed 27:10. No differences were seen for the onset of starter intake (Table 2). These data agree with previous work indicating that DFM supplementation in the MR does not influence DMI (Quigley et al., 1992; Cruywagen et al., 1996) but conflicts with other research that has found increased DMI when DFM was added to the diets of preweaned calves (Hughes, 1988). It is interesting to note that previous work found that supplementing DFM to transition and lactating cows resulted in increased DMI (Nocek et al., 2003; Nocek and Kautz, 2006), but because the mode of delivery and the physiological state of these animals differs from the calves used in the current trial, results are not comparable.

\section{Growth Data}

Birth weight was similar among all treatments (Table 3 ). Calves fed 27:10 had a greater overall BW compared with calves fed 22:20 and were heavier during preweaning. At weaning, calves fed 27:10 were $10.2 \mathrm{~kg}$ heavier than those fed 22:20 $(P<0.01$; Table 3$)$. Postweaning and final BW were not different, but a trend existed for heavier calves when fed 27:10 compared with 22:20 ( $P$ $<0.08)$. Changes in ADG were similar to those in BW. Calves fed 27:10 had greater ADG overall compared with those fed $22: 20$ (0.66 vs. $0.50 \mathrm{~kg} / \mathrm{d}$, respectively; $P<0.01$ ). Preweaning ADG was also greater in calves fed 27:10; however, no differences were detected in postweaning ADG, indicating that calves fed 22:20 exhibited compensatory gain postweaning, resulting in similar final BW and ADG.

Additionally, feed efficiency was not different, which is somewhat unexpected, given similar DMI and increased ADG. It is likely that the compensatory gain noted in calves fed 22:20 negated any differences in feed efficiency over the entire study.

Nonnecke et al. (2003) found similar results to the current study when they reported a $53 \%$ increase in mean BW at $60 \mathrm{~d}$ when calves were fed $30 \% \mathrm{CP}$ in the MR compared with $20 \%$. Increased ME intake (3.34 vs. $2.42 \mathrm{Mcal} / \mathrm{d} ; P<0.01)$ in that trial also yielded positive growth results, as calves consuming the accelerated MR had increased weaning BW by approximately 10 $\mathrm{kg}(P<0.01)$ and increased ADG $(0.61$ vs. $0.37 \mathrm{~kg} / \mathrm{d}$, respectively; $P<0.01)$ compared with calves fed the control MR. Bartlett et al. (2006) also noted an increase in ADG of over $0.1 \mathrm{~kg} / \mathrm{d}$ and $\mathrm{BW}$ at the end of the milk feeding period of over $10 \mathrm{~kg}$ when ME intake was greater for Holstein calves.

At weaning, calves fed 27:10 tended to have increased hip height $(P=0.06$; Table 3$)$ and had greater with- 
Table 1. Chemical composition (\% of DM, unless otherwise indicated; mean \pm SE) of starter and milk replacer (MR) offered and starter orts from Holstein calves

\begin{tabular}{|c|c|c|c|c|}
\hline \multirow[b]{2}{*}{ Item } & \multicolumn{4}{|c|}{ Diet $^{1}$} \\
\hline & $22: 20$ & $22: 20+\mathrm{D}$ & $27: 10$ & $27: 10+\mathrm{D}$ \\
\hline \multicolumn{5}{|l|}{ Starter } \\
\hline DM, \% & $90.7 \pm 0.58$ & & & \\
\hline $\mathrm{CP}$ & $22.6 \pm 0.40$ & & & \\
\hline Fat & $17.6 \pm 2.78$ & & & \\
\hline $\mathrm{NDF}$ & $22.7 \pm 0.52$ & & & \\
\hline $\mathrm{ADF}$ & $8.10 \pm 0.71$ & & & \\
\hline Ash & $12.0 \pm 0.71$ & & & \\
\hline \multicolumn{5}{|l|}{ MR powder } \\
\hline $\mathrm{DM}, \%$ & $95.1 \pm 0.17$ & & $93.6 \pm 0.18$ & \\
\hline $\mathrm{CP}$ & $21.7 \pm 0.24$ & & $28.7 \pm 0.14$ & \\
\hline Fat & $22.1 \pm 0.12$ & & $11.1 \pm 0.10$ & \\
\hline Ash & $11.8 \pm 0.20$ & & $13.0 \pm 0.01$ & \\
\hline $\mathrm{ME},{ }^{2} \mathrm{Mcal} / \mathrm{kg}$ & $4.49 \pm 0.01$ & & $3.96 \pm 0.004$ & \\
\hline \multicolumn{5}{|l|}{ Orts } \\
\hline DM, \% & $91.9 \pm 0.56$ & $91.7 \pm 0.69$ & $91.8 \pm 0.60$ & $91.9 \pm 0.63$ \\
\hline $\mathrm{CP}$ & $21.9 \pm 0.60$ & $21.8 \pm 0.43$ & $21.8 \pm 0.48$ & $21.7 \pm 0.60$ \\
\hline Fat & $15.9 \pm 1.86$ & $16.0 \pm 1.07$ & $16.2 \pm 1.62$ & $16.0 \pm 0.92$ \\
\hline NDF & $24.6 \pm 1.59$ & $24.0 \pm 1.19$ & $23.2 \pm 1.79$ & $23.3 \pm 1.33$ \\
\hline $\mathrm{ADF}$ & $8.8 \pm 1.20$ & $8.40 \pm 0.68$ & $8.30 \pm 0.84$ & $8.50 \pm 0.70$ \\
\hline
\end{tabular}

${ }^{1} 22: 20=$ control MR without direct-fed microbial (DFM) additive, with $22 \%$ protein and $20 \%$ fat; $22: 20+\mathrm{D}$ $=22: 20$ with the addition of a DFM (Calf RD; TechMix Inc., Stewart, MN); 27:10 = an accelerated MR with increased $\mathrm{CP}$ and decreased fat concentrations ( $27 \%$ protein and $10 \%$ fat); $27: 10+\mathrm{D}=27: 10$ with the addition of the DFM.

${ }^{2}$ Metabolizable energy $(\mathrm{Mcal} / \mathrm{kg}$ of DM) $=[0.057 \times \mathrm{CP}(\%)+0.092 \times$ fat $(\%)+0.0395 \times$ lactose $(\%)] \times$ 0.9312 .

ers height $(P=0.04)$ compared with calves fed 22:20. Calves fed 27:10 also had greater heart girth compared with those fed 22:20 $(P=0.02)$ at all stages of the trial (Table 3). These data agree with Brown et al. (2005), Cowles et al. (2006), Hill et al. (2008), and Raeth-Knight et al. (2009), who reported increased

Table 2. Daily intake $(\mathrm{kg} / \mathrm{d}$, unless otherwise indicated) and the onset of grain consumption in Holstein calves fed varying milk replacers (MR) with or without direct-fed microbial (DFM) supplementation

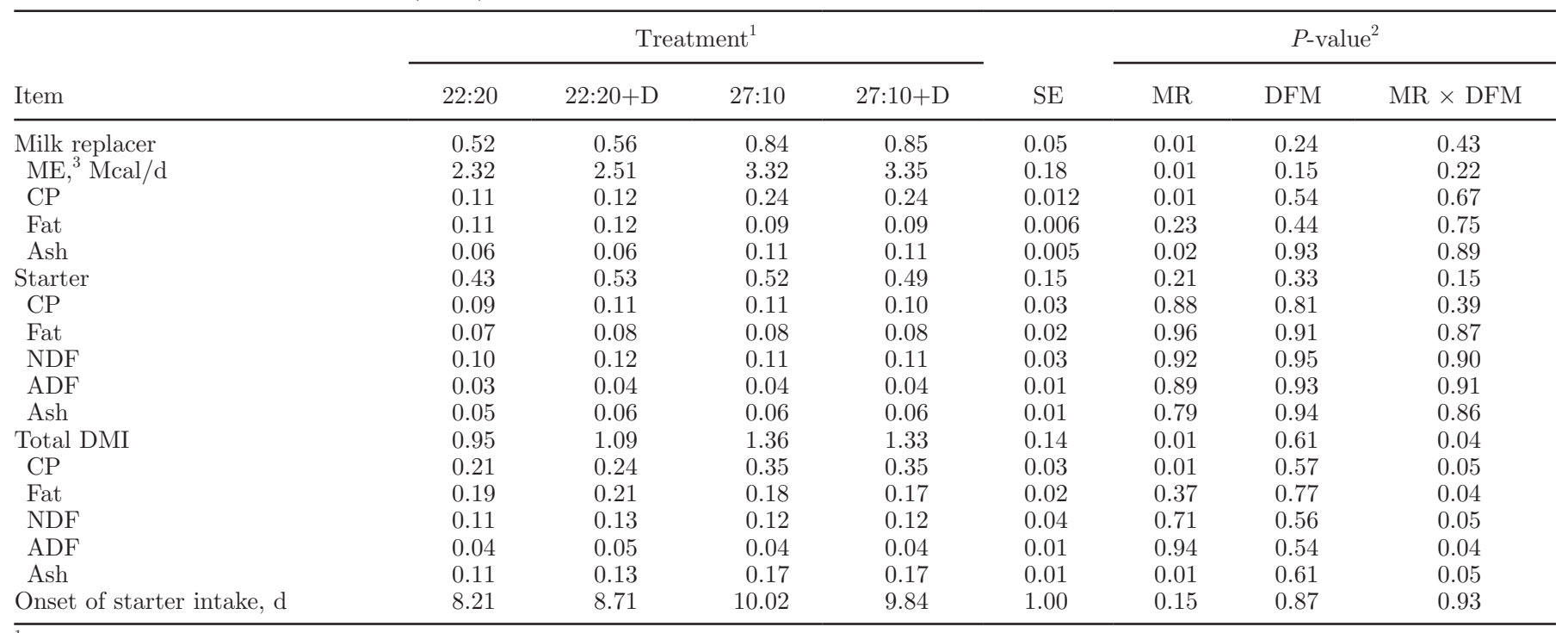

${ }^{1} 22: 20=$ control MR without DFM additive, with $22 \%$ protein and $20 \%$ fat; $22: 20+\mathrm{D}=22: 20$ with the addition of a DFM (Calf RD; TechMix Inc., Stewart, MN); 27:10 = an accelerated MR with increased $\mathrm{CP}$ and decreased fat concentrations $(27 \%$ protein and $10 \%$ fat $) ; 27: 10+\mathrm{D}=$ 27:10 with the addition of the DFM.

${ }^{2} P$-value for factorial effects. $\mathrm{MR}=$ main effect of $\mathrm{MR}$; DFM $=$ main effect of DFM; MR $\times \mathrm{DFM}=$ cumulative effect of MR and DFM.

${ }^{3}$ Metabolizable energy $(\mathrm{Mcal} / \mathrm{kg}$ of $\mathrm{DM})=[0.057 \times \mathrm{CP}(\%)+0.092 \times$ fat $(\%)+0.0395 \times$ lactose $(\%)] \times 0.9312$. 
Table 3. Body weight, growth measures, and feed efficiency in Holstein calves fed varying milk replacers (MR) with or without direct-fed microbial (DFM) supplementation

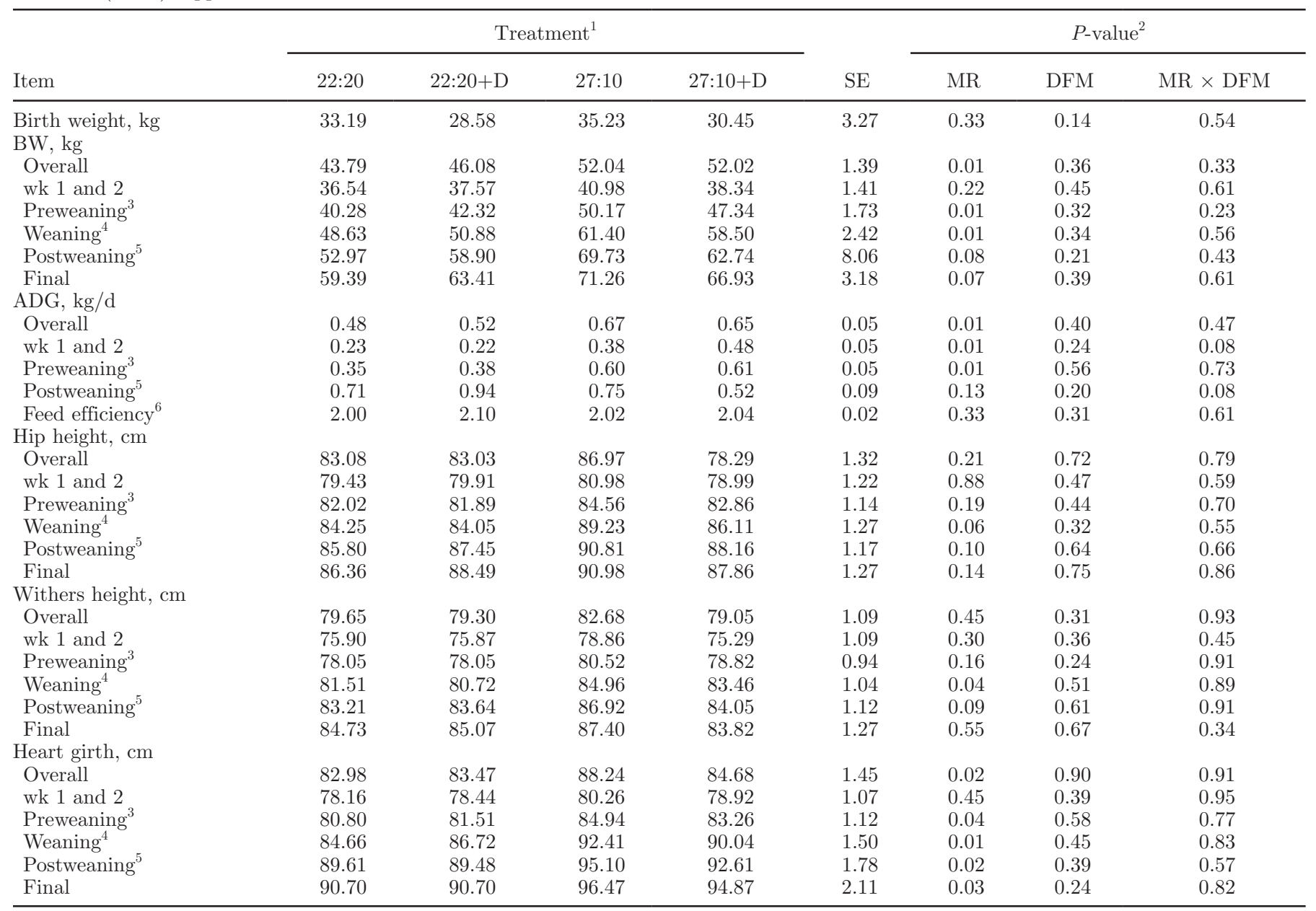

${ }^{1} 22: 20=$ control MR without DFM additive, with $22 \%$ protein and $20 \%$ fat; $22: 20+\mathrm{D}=22: 20$ with the addition of a DFM (Calf RD; TechMix Inc., Stewart, MN); 27:10 = an accelerated MR with increased $\mathrm{CP}$ and decreased fat concentrations $(27 \%$ protein and $10 \%$ fat $) ; 27: 10+\mathrm{D}=$ 27:10 with the addition of the DFM.

${ }^{2} P$-value for factorial effects. $\mathrm{MR}=$ main effect of $\mathrm{MR}$; DFM $=$ main effect of DFM; MR $\times \mathrm{DFM}=$ cumulative effect of MR and DFM.

${ }^{3}$ Preweaning period indicates birth until 6 wk of age.

${ }^{4}$ Weaning occurred at $6 \mathrm{wk}$ of age.

${ }^{5}$ Postweaning period indicates weaning (wk 6) until 8 wk of age.

${ }^{6}$ Feed efficiency $=$ intake $(\mathrm{kg}) / \mathrm{ADG}(\mathrm{kg} / \mathrm{d})$.

Table 4. Daily observations in Holstein calves fed varying milk replacers (MR) with or without direct-fed microbial (DFM) supplementation

\begin{tabular}{|c|c|c|c|c|c|c|c|c|}
\hline Item & \multicolumn{4}{|c|}{ Treatment $^{1}$} & $\mathrm{SE}$ & \multicolumn{3}{|c|}{$P$-value ${ }^{2}$} \\
\hline Respiration rate, beats/min & 53.41 & 50.73 & 51.77 & 52.43 & 1.30 & 0.87 & 0.74 & 0.18 \\
\hline Fecal score ${ }^{4}$ & 2.00 & 2.46 & 2.10 & 2.67 & 0.08 & 0.18 & 0.01 & 0.08 \\
\hline Rectal temperature, ${ }^{\circ} \mathrm{C}$ & 38.97 & 38.79 & 38.81 & 38.77 & 0.08 & 0.18 & 0.41 & 0.40 \\
\hline
\end{tabular}

${ }^{1} 22: 20=$ control MR without DFM additive, with $22 \%$ protein and $20 \%$ fat; $22: 20+\mathrm{D}=22: 20$ with the addition of a DFM (Calf RD; TechMix Inc., Stewart, MN); 27:10 = an accelerated MR with increased $\mathrm{CP}$ and decreased fat concentrations $(27 \%$ protein and $10 \%$ fat $) ; 27: 10+\mathrm{D}=$ 27:10 with the addition of the DFM.

${ }^{2} P$-value for factorial effects. $\mathrm{MR}=$ main effect of $\mathrm{MR} ; \mathrm{DFM}=$ main effect of DFM; MR $\times \mathrm{DFM}=$ cumulative effect of MR and DFM.

${ }^{3}$ Five-point scale, where $1=$ normal, 2 = runny nose, $3=$ heavy breathing, $4=$ moist cough, and $5=$ dry cough (Larson et al., 1977).

${ }^{4}$ Four-point scale, where $1=$ normal, 2 = soft, 3 = runny, and 4 = watery (Larson et al., 1977). 
Table 5. Rumen measures ( $\mathrm{pH}$ and VFA) in Holstein calves fed varying milk replacers (MR) with or without direct-fed microbial (DFM) supplementation

\begin{tabular}{|c|c|c|c|c|c|c|c|c|}
\hline \multirow[b]{2}{*}{ Item } & \multicolumn{4}{|c|}{ Treatment $^{1}$} & \multirow[b]{2}{*}{$\mathrm{SE}$} & \multicolumn{3}{|c|}{$P$-value ${ }^{2}$} \\
\hline & $22: 20$ & $22: 20+\mathrm{D}$ & $27: 10$ & $27: 10+\mathrm{D}$ & & MR & DFM & $\mathrm{MR} \times \mathrm{DFM}$ \\
\hline Acetate, $\mathrm{mmol} / \mathrm{L}$ & 25.6 & 27.2 & 22.8 & 22.9 & 3.09 & 0.01 & 0.34 & 0.45 \\
\hline Propionate, $\mathrm{mmol} / \mathrm{L}$ & 17.4 & 20.4 & 15.8 & 14.2 & 2.61 & 0.01 & 0.51 & 0.23 \\
\hline Butyrate, $\mathrm{mmol} / \mathrm{L}$ & 4.35 & 3.29 & 2.41 & 2.53 & 0.61 & 0.02 & 0.26 & 0.44 \\
\hline Isobutyrate, $\mathrm{mmol} / \mathrm{L}$ & 0.48 & 0.53 & 0.41 & 0.41 & 0.07 & 0.09 & 0.62 & 0.54 \\
\hline
\end{tabular}

${ }^{1} 22: 20=$ control MR without DFM additive, with $22 \%$ protein and $20 \%$ fat; $22: 20+\mathrm{D}=22: 20$ with the addition of a DFM (Calf RD; TechMix Inc., Stewart, MN); 27:10 = an accelerated MR with increased CP and decreased fat concentrations $(27 \%$ protein and $10 \%$ fat $) ; 27: 10+\mathrm{D}=$ 27:10 with the addition of the DFM.

${ }^{2} P$-value for factorial effects. $\mathrm{MR}=$ main effect of $\mathrm{MR}$; DFM $=$ main effect of DFM; MR $\times \mathrm{DFM}=$ cumulative effect of $\mathrm{MR}$ and DFM.

frame measurements before and at weaning when $\mathrm{CP}$ concentration in the MR was increased. Other work has also shown frame measures to increase when ME intake was greater in preweaned calves, although this was by design, as calves consuming more ME were fed at a greater feeding rate (Bartlett et al., 2006). Supplementation with DFM did not affect any growth measures in the current trial.

\section{Health Observations}

All calves on trial had adequate passive immunity transfer from their dams (data not shown). Respiration rate and respiration score were unaffected by treatment, but values were within a normal range (Table 4). Milk replacer did not affect fecal score, but calves fed DFM had greater fecal scores compared with those not fed DFM $(P<0.01)$. A tendency $(P$ $=0.08$ ) existed for an interaction of MR and DFM supplementation on fecal scores, where calves fed 27:10+D had the greatest fecal scores. Galvão et al. (2005) found that immune-compromised calves had fewer days with scours when supplemented with live yeast, further indicating that DFM may have less of an effect in healthy animals. Rectal temperature was unaffected by treatment.

\section{Rumen Measurements}

No treatment differences were found for ruminal $\mathrm{pH}$ (Table 5). Calves fed 22:20 had greater acetate, propionate, and butyrate concentrations compared with

Table 6. Blood gas, electrolytes, and metabolites in Holstein calves fed varying milk replacers (MR) with or without direct-fed microbial (DFM) supplementation

\begin{tabular}{|c|c|c|c|c|c|c|c|c|}
\hline \multirow[b]{2}{*}{ Item } & \multicolumn{4}{|c|}{ Treatment $^{1}$} & \multirow[b]{2}{*}{$\mathrm{SE}$} & \multicolumn{3}{|c|}{$P$-value ${ }^{2}$} \\
\hline & $22: 20$ & $22: 20+\mathrm{D}$ & $27: 10$ & $27: 10+\mathrm{D}$ & & $\mathrm{MR}$ & DFM & $\mathrm{MR} \times \mathrm{DFM}$ \\
\hline $\mathrm{p}_{\mathrm{CO}_{2}},{ }^{3} \mathrm{~mm}$ of $\mathrm{Hg}$ & 49.87 & 50.61 & 52.52 & 53.74 & 0.86 & 0.01 & 0.24 & 0.77 \\
\hline $\mathrm{HCO}_{3}{ }^{-4}, \mathrm{mmol} / \mathrm{L}$ & 29.31 & 29.71 & 30.43 & 30.42 & 0.42 & 0.02 & 0.63 & 0.61 \\
\hline Anion gap, mmol/L & 12.04 & 11.99 & 11.79 & 11.67 & 0.37 & 0.41 & 0.82 & 0.92 \\
\hline $\mathrm{tCO}_{2},{ }^{5} \mathrm{mmol} / \mathrm{L}$ & 30.83 & 31.10 & 31.95 & 32.06 & 0.43 & 0.01 & 0.64 & 0.84 \\
\hline $\mathrm{Cl}^{-}, \mathrm{mmol} / \mathrm{L}$ & 103.53 & 103.11 & 103.44 & 103.59 & 0.32 & 0.52 & 0.67 & 0.35 \\
\hline Hematocrit, \% & 52.03 & 50.69 & 56.66 & 51.17 & 3.11 & 0.35 & 0.25 & 0.45 \\
\hline Serum protein, $\mathrm{g} / 100 \mathrm{~mL}$ & 6.49 & 6.12 & 6.12 & 6.16 & 0.12 & 0.11 & 0.15 & 0.05 \\
\hline Blood glucose, mg/dL & 70.75 & 76.70 & 77.75 & 76.12 & 3.71 & 0.35 & 0.55 & 0.27 \\
\hline
\end{tabular}

${ }_{1} 22: 20=$ control MR without DFM additive, with $22 \%$ protein and $20 \%$ fat; $22: 20+\mathrm{D}=22: 20$ with the addition of a DFM (Calf RD; TechMix Inc., Stewart, MN); 27:10 = an accelerated MR with increased CP and decreased fat concentrations $(27 \%$ protein and $10 \%$ fat $) ; 27: 10+\mathrm{D}=$ 27:10 with the addition of the DFM.

${ }^{2} P$-value for factorial effects. MR = main effect of MR; DFM = main effect of DFM; MR $\times$ DFM $=$ cumulative effect of MR and DFM.

${ }^{3}$ Partial pressure of carbon dioxide.

${ }^{4}$ Bicarbonate.

${ }^{5}$ Total bicarbonate. 

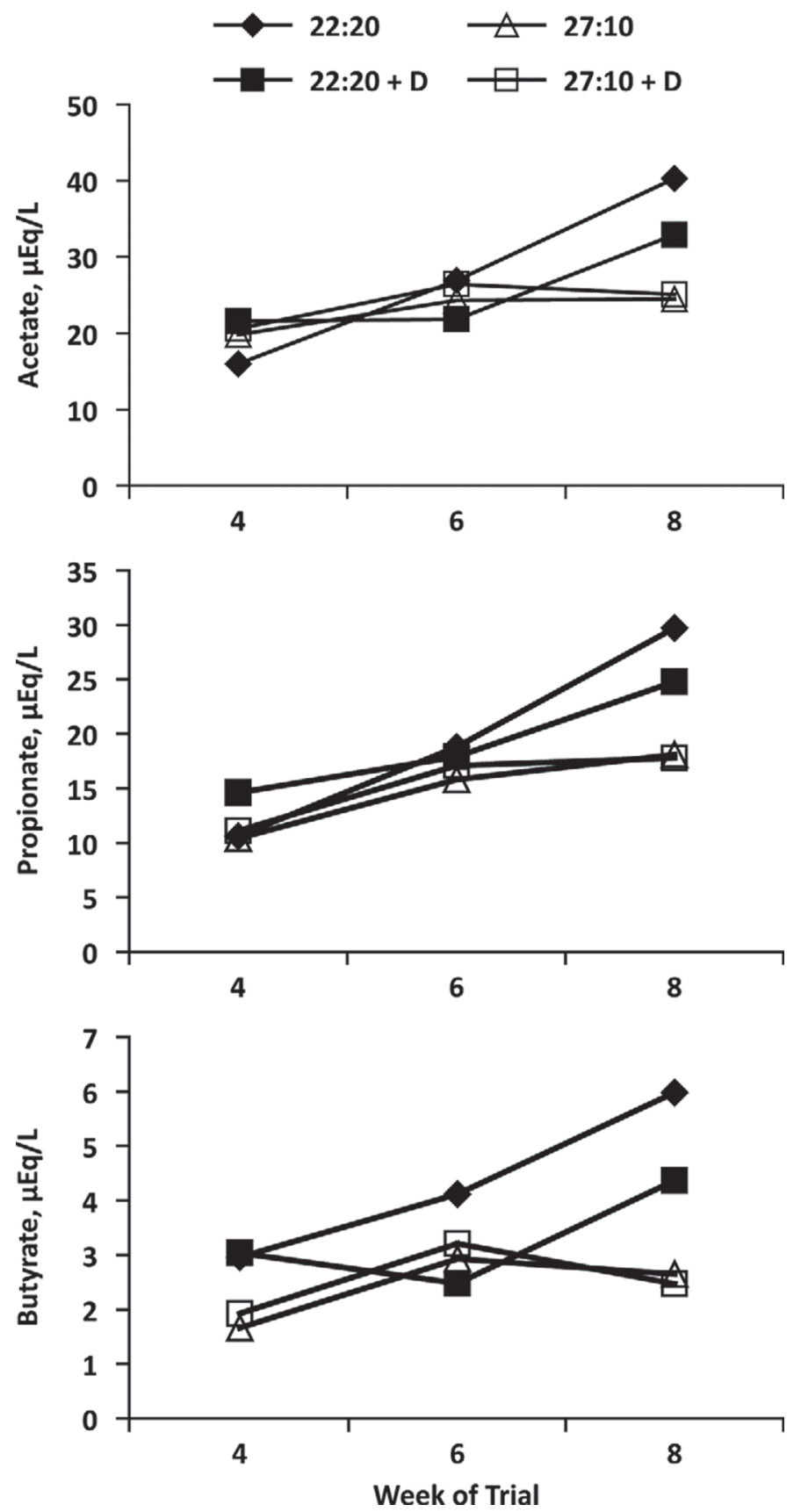

Figure 1. Ruminal VFA (acetate, propionate, and butyrate) concentrations in Holstein calves fed varying milk replacers with or without direct-fed microbial (DFM) supplementation. 22:20 = control milk replacer (MR) without DFM additive, with $22 \%$ protein and $20 \%$ fat; $22: 20+\mathrm{D}=22: 20$ with the addition of a DFM (Calf RD; TechMix Inc., Stewart, MN); 27:10 = an accelerated MR with increased $\mathrm{CP}$ and decreased fat concentrations ( $27 \%$ protein and $10 \%$ fat $) ; 27: 10+\mathrm{D}=$ 27:10 with the addition of the DFM.

calves fed 27:10 $(P<0.01, P<0.01$, and $P=0.02$, respectively; Table 5). No differences were found for isovalerate, but calves fed 22:20 tended to have greater isobutyrate concentrations compared with calves fed 27:10 $(P=0.09)$. Calves fed 22:20 had greater acetate
$(P<0.01)$ and propionate $(P<0.01)$ concentrations in the rumen fluid compared with calves fed 27:10 during wk 8 of the trial (Figure 1). Butyrate concentrations during wk 8 were increased in calves fed 22:20 compared with 27:10 $(P<0.01)$. During wk 4 , calves fed either of the 22:20 treatments had greater butyrate concentrations compared with calves fed the 27:10 treatments $(P<0.01)$. Direct-fed microbial supplementation did not have an effect on any VFA measurements. Thus, it appears that VFA concentrations were positively influenced when the 22:20 MR was fed to calves.

\section{Blood Metabolite Data}

Blood $\mathrm{pH}$ was not different according to treatment, but values were in a normal range (Table 6). Partial pressure of $\mathrm{CO}_{2}\left(\mathbf{p}_{\mathrm{CO}_{2}}\right)$ increased in calves fed 27:10 compared with calves fed 22:20 $(P<0.01)$. Partial pressure of $\mathrm{CO}_{2}$ is affected by $\mathrm{pH}$ and respiration (Kadzere et al., 2002). The fact that $\mathrm{p}_{\mathrm{CO}_{2}}$ was different whereas $\mathrm{pH}$ remained the same remains unexplained. Bicarbonate $\left(\mathbf{H C O}_{3}{ }^{-}\right)$and total bicarbonate $\left(\mathbf{t C O}_{2}\right)$ react similar to $\mathrm{p}_{\mathrm{CO}_{2}}$ as they try to remain in constant balance with $\mathrm{p}_{\mathrm{CO}_{2}}$. The fact $\mathrm{HCO}_{3}{ }^{-}$and $\mathrm{tCO}_{2}$ reacted similarly to $\mathrm{p}_{\mathrm{CO}_{2}}$ and were greater in calves fed 27:10 was expected and agrees with previous research indicating that $\mathrm{p}_{\mathrm{CO}_{2}}, \mathrm{HCO}_{3}{ }^{-}$, and $\mathrm{tCO}_{2}$ respond in a similar pattern in dairy animals to remain in balance with each other to keep the animal from entering an acidotic or physiologically unstable state (Kadzere et al., 2002; Srikandakumar and Johnson, 2004). Calves fed 22:20 had greater serum protein concentrations compared with $22: 20+\mathrm{D}, 27: 10$, and $27: 10+\mathrm{D}$ (6.49 vs. $6.12,6.12$, and $6.16 \mathrm{~g} / 100 \mathrm{~mL}$, respectively; $P<0.05$; Table 6$)$. Galvão et al. (2005) found an increase in blood glucose concentration when calves were supplemented with DFM in the grain for the first $82 \mathrm{~d}$ of life as a result of more nutrients being available to the calf. In the current study, blood glucose concentration was not different; however, the DFM was not delivered in the starter, so it is possible that delivery method could affect effectiveness of the DFM. No treatment differences were found for anion gap, $\mathrm{Na}^{+}, \mathrm{K}^{+}, \mathrm{Cl}^{-}$, or hematocrit, but anion gap $(P<0.01)$ and $\mathrm{K}^{+}$were affected by week $(P$ $<0.01$; data not shown).

In conclusion, this study indicates and further confirms the benefits of increased $\mathrm{CP}$ and ME intake during the preweaning period. Consuming accelerated MR (27:10 or 27:10+D) increased CP and ME intake in calves, and in turn, positively affected BW, frame measures, and ADG throughout the trial. Direct-fed microbial supplementation was unable to successfully promote intake, growth, or rumen measures in this 
study. In addition, DFM supplementation increased fecal scores in calves during this trial. It can be concluded that accelerated MR should continue to be used to achieve increased nutrient intake and growth rates preweaning and increased BW at weaning. However, DFM supplementation appeared ineffective when delivered in the milk and no cumulative treatment effects were realized in this study.

\section{ACKNOWLEDGMENTS}

The authors acknowledge TechMix Inc. (Stewart, $\mathrm{MN}$ ) for partial funding of this trial and Land O'Lakes, Inc. (St. Paul, MN) for providing product for the trial. The authors also thank the Mississippi Agriculture and Forestry Experiment Station (MAFES, Mississippi State) for partial funding and other resources in completing this trial. Additionally, this work was completed, in part, to fulfill a research objective of the NC 2042 multi-state research group.

\section{REFERENCES}

AOAC. 1990. Official Methods of Analysis. 15th ed. Association of Official Analytical Chemists, Washington, DC.

Bartlett, K. S., F. K. McKeith, M. J. VandeHaar, G. E. Dahl, and J. K. Drackley. 2006. Growth and body composition of dairy calves fed milk replacers containing different amounts of protein at two feeding rates. J. Anim. Sci. 84:1454-1467.

Bateman, H. G., II, C. C. Williams, and Y. H. Chung. 2002. Effects of supplemental zinc in high quality diets on ruminal fermentation and degradation of urea in vitro and in vivo. Prof. Anim. Sci. 18:363-367.

Blome, R. M., J. K. Drackley, F. K. McKeith, M. F. Hutjens, and G. C. McCoy. 2003. Growth, nutrient utilization, and body composition of dairy calves fed milk replacers containing different amounts of protein. J. Anim. Sci. 81:1641-1655.

Brown, E. G., M. J. VandeHaar, K. M. Daniels, J. S. Liesman, L. T. Chaplin, D. H. Keisler, and M. S. Weber Nielsen. 2005. Effect of increasing energy and protein intake on body growth and carcass composition of heifer calves. J. Dairy Sci. 88:585-594.

Cowles, K. E., R. A. White, N. L. Whitehouse, and P. S. Erickson. 2006. Growth characteristics of calves fed an intensified milk replacer regimen with additional lactoferrin. J. Dairy Sci. 89:48354845.

Cruywagen, C. W., I. Jordaan, and L. Venter. 1996. Effect of Lactobacillus acidophilus supplementation of milk replacer on preweaning performance of calves. J. Dairy Sci. 79:483-486.
Galvão, K. N., J. E. P. Santos, A. Coscioni, M. Villaseñor, W. M. Sischo, and A. C. B. Berge. 2005. Effect of feeding live yeast products to calves with failure of passive transfer on performance and patterns of antibiotic resistance in fecal Escherichia coli. Reprod. Nutr. Dev. 45:427-440.

Goering, H. K., and P. J. Van Soest. 1970. Forage fiber analysis (apparatus, reagents, procedures, and some applications). USDA Agricultural Handbook No. 379. USDA, Washington, DC

Grigsby, K. N., M. S. Kerley, J. A. Paterson, and J. C. Weigel. 1992. Site and extent of nutrient digestion by steers fed a low-quality bromegrass hay diet with incremental levels of soybean hull substitutions. J. Anim. Sci. 70:1941-1949.

Hill, S. R., K. F. Knowlton, K. M. Daniels, R. E. James, R. E. Pearson, A. V. Capuco, and R. M. Akers. 2008. Effects of milk replacer composition on growth, body composition, and nutrient excretion in preweaned Holstein heifers. J. Dairy Sci. 91:3145-3155.

Hughes, J. 1988. The effect of high strength yeast culture in diets of early-weaned calves. Anim. Prod. 45:526.

Kadzere, C. T., M. R. Murphy, N. Silanikove, and E. Maltz. 2002. Heat stress in lactating dairy cows: A review. Livest. Prod. Sci. 77:59-91

Larson, L. L., F. G. Owen, J. L. Albright, R. D. Appleman, R. C. Lamb, and L. D. Muller. 1977. Guidelines toward more uniformity in measuring and reporting calf experimental data. J. Dairy Sci. 60:989-991.

Lassiter, C. A., L. D. Brown, R. M. Grimes, and C. W. Duncan. 1963. Effect of protein level in milk replacers on growth and protein metabolism of dairy calves. J. Dairy Sci. 46:538-543.

NRC. 2001. Nutrient Requirements of Dairy Cattle. National Academy Press, Washington, DC.

Nocek, J. E., and W. P. Kautz. 2006. Direct-fed microbial supplementation on ruminal digestion, health, and performance of pre- and postpartum dairy cattle. J. Dairy Sci. 89:260-266.

Nocek, J. E., W. P. Kautz, J. A. Leedle, and E. Block. 2003. Direct-fed microbial supplementation on the performance of dairy cattle during the transition period. J. Dairy Sci. 86:331-335.

Nonnecke, B. J., M. R. Foote, J. M. Smith, B. A. Pesch, and M. E. Van Amburgh. 2003. Composition and functional capacity of blood mononuclear leukocyte populations from neonatal calves on standard and intensified milk replacer diets. J. Dairy Sci. 86:3592-3604

Quigley, J. D., III, L. B. Wallis, H. H. Dowlen, and R. N. Heitmann. 1992. Sodium bicarbonate and yeast culture effects on ruminal fermentation, growth, and intake in dairy calves. J. Dairy Sci. $75: 3531-3538$.

Raeth-Knight, M., H. Chester-Jones, S. Hayes, J. Linn, R. Larson, D. Ziegler, B. Ziegler, and N. Broadwater. 2009. Impact of conventional or intensive milk replacer programs on Holstein heifer performance through six months of age and during first lactation. J. Dairy Sci. 92:799-809.

SAS Institute. 2004. SAS User's Guide: Statistics. Version 9.2. SAS Institute Inc., Cary, NC.

Srikandakumar, A., and E. H. Johnson. 2004. Effects of heat stress on milk production, rectal temperature, respiratory rate and blood chemistry in Holstein, Jersey, and Australian milking Zebu cows. Trop. Anim. Health Prod. 36:685-692. 